\title{
Normal Genes for the Cholesterol Side Chain Cleavage Enzyme, P450scc, in Congenital Lipoid Adrenal Hyperplasia
}

\author{
Dong Lin," Stephen E. Gitelman, * Paul Saenger," and Walter L. Miller** \\ ${ }^{*}$ Department of Pediatrics and ${ }^{\ddagger}$ The Metabolic Research Unit, University of California, San Francisco, California 94143 , \\ and ${ }^{\S}$ Department of Pediatrics, Albert Einstein College of Medicine, New York 10467
}

\begin{abstract}
Congenital lipoid adrenal hyperplasia is the most severe form of congenital adrenal hyperplasia. Affected individuals can synthesize no steroid hormones, and hence are all phenotypic females with a severe salt-losing syndrome that is fatal if not treated in early infancy. All previous studies have suggested that the disorder is in the cholesterol side chain cleavage enzyme (P450scc), which converts cholesterol to pregnenolone. A newborn patient was diagnosed by the lack of significant concentrations of adrenal or gonadal steroids either before or after stimulation with corticotropin (ACTH) or gonadotropin (hCG). The P450sce gene in this patient and in a previously described patient were grossly intact, as evidenced by Southern blotting patterns. Enzymatic (polymerase chain reaction) amplification and sequencing of the coding regions of their P450scc genes showed these were identical to the previously cloned human P450sce cDNA and gene sequences. Undetected compound heterozygosity was ruled out in the new patient by sequencing P450sce cDNA enzymatically amplified from gonadal RNA. Northern blots of gonadal RNA from this patient contained normal sized mRNAs for P450sce and also for adrenodoxin reductase, adrenodoxin, sterol carrier protein 2, endozepine, and GRP-78 (the precursor to steroidogenesis activator peptide). These studies show that lipoid CAH is not caused by lesions in the P450sce gene, and suggest that another unidentified factor is required for the conversion of cholesterol to pregnenolone, and is disordered in congenital lipoid adrenal hyperplasia. (J. Clin. Invest. 1991. 88:1955-1962.) Key words: pregnenolone • pseudohermaphroditism • cholesterol desmolase • polymerase chain reaction $\bullet$ sex steroids
\end{abstract}

\section{Introduction}

Congenital adrenal hyperplasia (CAH) ${ }^{1}$ is a group of inborn errors of steroid hormone synthesis. Distinct autosomal recessive forms of $\mathrm{CAH}$ have been described for each step in the conversion of cholesterol to the principal secretory products of

Address all correspondence to Walter L. Miller, M.D., Bldg. MR-IV, Room 209, University of California San Francisco, San Francisco, CA 94143-0978.

Received for publication 17 May 1991 and in revised form $07 \mathrm{Au}$ gust 1991

1. Abbreviations used in this paper: $\mathrm{CAH}$, congenital adrenal hyperplasia; hCG, gonadotropin; PCR, polymerase chain reaction; PRA, plasma renin activity.

J. Clin. Invest.

(c) The American Society for Clinical Investigation, Inc.

$0021-9738 / 91 / 12 / 1955 / 08 \quad \$ 2.00$

Volume 88, December 1991, 1955-1962 the adrenals (for reviews see references 1,2 ). Because the enzymes responsible for adrenal steroidogenesis also participate in gonadal steroidogenesis, many forms of CAH also affect gonadal sex steroid synthesis.

The most severe form of CAH is congenital lipoid adrenal hyperplasia (lipoid CAH). This disorder is characterized by an absence of significant circulating or urinary concentrations of all steroids, high basal concentrations of adrenocorticotropin (ACTH) and plasma renin activity (PRA), absent steroidal response to long-term treatment with high doses of ACTH or human chorionic gonadotropin (hCG), and grossly enlarged adrenals laden with cholesterol and cholesterol esters (3-6). These findings have suggested that the lesion is in the first step in steroidogenesis, the conversion of cholesterol to pregnenolone. Enzymologic studies (6-9) confirmed that adrenal and gonadal tissue from these patients failed to convert cholesterol to pregnenolone, consistent with the notion that the lesion is in the enzyme converting cholesterol to pregnenolone.

The conversion of cholesterol to pregnenolone is mediated by a single mitochondrial enzyme, cytochrome P450scc (EC 1.14.15.67) (for reviews see references 10-12). P450scc functions as the terminal oxidase in an electron transport chain. Electrons from NADPH are donated to a membranebound flavoprotein, termed adrenodoxin reductase, then passed to a soluble iron/sulfur protein, termed adrenodoxin, and then passed to P450scc. Congenital lipoid adrenal hyperplasia might conceivably be caused by a genetic lesion in any of the three components of the side-chain cleavage system. In one autopsied patient, P450scc protein was undetectable (9), thus implying that the lesion was in P450scc. A lesion in adrenodoxin reductase or adrenodoxin appears most unlikely. Adrenodoxin and adrenodoxin reductase have been isolated from various tissues with properties indistinguishable from the adrenal proteins (for references see 13). These proteins thus interact with many other mitochondrial cytochrome P450 enzymes, such as hepatic bile acid 26-hydroxylase/vitamin D 25-hydroxylase, $(14,15)$ or renal vitamin D 1-hydroxylase (16). There is only one human gene for adrenodoxin reductase, located on chromosome 17q24-q25 (17-19) that is expressed in all human tissues examined, (20) hence a disorder in this gene should have effects extending far beyond the steroidogenic tissues. Similarly, there are one (21) or two (22) nearly identical genes for adrenodoxin closely linked on chromosome 11 q22 $(19,22,23)$ that encode identical proteins (23); this mRNA is also found in all tissues examined (24). Thus, it has generally been agreed that congenital lipoid adrenal hyperplasia represents a genetic defect in the human P450scc gene $(1,25)$.

To date, only one study has directly examined the P450scc genes in patients with lipoid CAH. Matteson et al. (26) used oligonucleotide probes and a partial-length P450scc cDNA to probe Southern blots of DNA from three patients and various controls, finding no deletions, rearrangements, or restriction 
Table I. Basal and Tropicly Stimulated Hormonal Values in Case 1

\begin{tabular}{|c|c|c|c|c|c|c|}
\hline \multirow[b]{2}{*}{ Steroid $(n g / d l)$} & \multicolumn{2}{|c|}{ No treatment } & \multirow{2}{*}{$\begin{array}{c}0.25 \mathrm{mg} \\
\text { ACTH gel } \\
22 \mathrm{~d}\end{array}$} & \multirow{2}{*}{$\begin{array}{c}5000 \text { U hCG } \\
\text { M, W, F } \\
24 \mathrm{~d}\end{array}$} & \multirow{2}{*}{$\begin{array}{l}\text { Normal term } \\
\text { infants at } \\
7-30 \mathrm{~d}\end{array}$} & \multirow{2}{*}{$\begin{array}{c}\text { Normal term } \\
\text { infants } \\
\text { post-hCG }\end{array}$} \\
\hline & Age: $\mathbf{2 d}$ & $10 \mathrm{~d}$ & & & & \\
\hline Pregnenolone & 50 & 114 & & $<70$ & $150-2000$ & \\
\hline $17 \mathrm{OH}$ pregnenolone & & $<20$ & & & $100-3000$ & \\
\hline $17 \mathrm{OH}$ progesterone & & 30 & 1.9 & & $60-150$ & \\
\hline Dehydroepiandrosterone & & $<20$ & 11 & $<10$ & $50-760$ & \\
\hline Androstenedione & 16 & 29 & & 6.0 & $20-290$ & \\
\hline Corticosterone & $<50$ & $<50$ & & & $70-850$ & \\
\hline Cortisol ( $\mu \mathrm{g} / \mathrm{dl})$ & $<1.0$ & 2.2 & $<1$ & & $2-11$ & \\
\hline Aldosterone & 8.5 & 3.8 & 1 & & $5-175$ & \\
\hline Testosterone & & & & $<3$ & $60-400^{*}$ & $180-735$ \\
\hline Dihydrotesterosterone & & & & $<2.7$ & $12-85^{*}$ & $13-183$ \\
\hline
\end{tabular}

* At 20-60 d age. Hormonal studies in patient No. 1.

fragment length variations in the P450scc gene. However, the more recent cloning and characterization of the single human P450scc gene (27) on chromosome 15q23-q24 (19) indicates that the oligonucleotides and partial-length cDNA used in that study could have missed deletions at the $5^{\prime}$ end of the gene.

We now report a new case of lipoid $\mathrm{CAH}$, and the sequencing of the cDNA and the exons for this patient's P450scc gene and of the gene from our previously reported patient (6). The normal P450scc gene sequences in these two patients and the grossly normal RNA blotting studies of all of the components of the cholesterol side chain cleavage system and known components of the cholesterol transport system indicate that new models of this disorder must be considered, possibly searching for other factors in the delivery of cholesterol to the mitochondria.

\section{Case reports}

Case 1. A 3,320-g newborn Korean infant without known consanguinity was referred to one of us (PS) because of a 6.5-yr-old female sibling had previously been diagnosed as having congenital adrenal hyperplasia due to $3 \beta$-hydroxysteroid dehydrogenase deficiency (see below). Physical examination at $2 \mathrm{~d}$ of age was unremarkable except for generalized increased pigmentation and normal female external genitalia. Initial laboratory data included serum $\mathrm{Na}, 139 \mathrm{mEq} /$ liter; $\mathrm{K}, 6.1 \mathrm{mEq} / \mathrm{liter} ; \mathrm{CO}_{2}$, $20 \mathrm{mEq} /$ liter; glucose, $74 \mathrm{mg} / \mathrm{dl}$; and various hormonal values (Table I). Urinary excretion of 17-ketosteroids was $0.05 \mathrm{mg} / 24$ h. Pelvic sonography was technically unsatisfactory. The infant gained weight poorly and developed hypotonia and hyperthermia. At $10 \mathrm{~d}$ of age the respiratory rate was 36 , the heart rate was 140 . Laboratory data included serum $\mathrm{Na}, 113 \mathrm{mEq} / \mathrm{liter}$ $\mathrm{K}, 9.0 \mathrm{mEq} /$ liter; $\mathrm{CO}_{2}, 15 \mathrm{mEq} /$ liter; $\mathrm{Cl}, 90 \mathrm{mEq} /$ liter; glucose, $111 \mathrm{mg} / \mathrm{dl}$; and further hormonal values (Table I). All steroid values in Tables I and II were determined by Endocrine Sciences, Tarzana, CA, by chromatographic extraction followed by specific immunoassays.

The infant was treated with intravenous saline, hydrocortisone, and fluodrocortisone and did well. A karyotype obtained at $2 \mathrm{~d}$ of age was $46 \mathrm{XY}$. Further provocative testing of the adrenals and gonads was done by administering a single dose of 0.25 mg synthetic ACTH (1-39) gel (Acthar; Armour Pharmaceutical Co., Tarrytown, NY), and 5,000 U of hCG IM on Monday, Wednesday, and Friday before drawing blood sam- ples on the following Monday, yielding the values shown in Table I. Other studies included normal thyroid function studies and a plasma ACTH of $585 \mathrm{pg} / \mathrm{ml}$ at $40 \mathrm{~d}$ of age (normal $\leq 100 \mathrm{pg} / \mathrm{ml}$ ).

At 6.5 mo of age a gonadectomy was performed. The internal reproductive structures included undescended testes each measuring $9 \times 5 \times 5 \mathrm{~mm}$, and no Müllerian structures (fallopian tubes, uterus, cervix) consistent with testicular synthesis of Müllerian inhibitory factor but not of steroids $(28,29)$. The histologic examination of the gonadal tissue showed normal testes bilaterally.

Recent hormonal reevaluation of the 7-yr-old 46 XX sibling showed low but detectable concentrations of adrenal steroids with no response to $0.25 \mathrm{mg}$ of intravenous ACTH (1-24) (Cortrosyn; Organon Diagnostics, West Orange, NJ) at a time when steroidal replacement therapy was discontinued for $36 \mathrm{~h}$ (Table II). Thus, both siblings appear to have the same, presumably autosomal recessive defect in the synthesis of all steroid hormones.

Case 2. The clinical, laboratory, radiographic, and biochemical findings in case 2 have been reported in detail previously (6). Her DNA was also included in the study of Matteson et al. (26) as patient No. 1 .

Table II. Hormonal Values in the Sibling of Case 1

\begin{tabular}{|c|c|c|c|c|}
\hline \multirow[b]{2}{*}{ Steroid $(n g / d l)$} & \multicolumn{2}{|c|}{ Patient } & \multicolumn{2}{|c|}{ NL prepubertal girls } \\
\hline & Basal & $60^{\circ}$ АCTH & Basal & $60^{\prime}$ ACTH \\
\hline Pregnenolone & 15 & 27 & $31 \pm 16$ & $77 \pm 23$ \\
\hline Progesterone & $<20$ & $<20$ & $26 \pm 12$ & $144 \pm 15.5$ \\
\hline $17 \mathrm{OH}$ pregnenolone & 53 & $<20$ & $59 \pm 43$ & $354 \pm 186$ \\
\hline $17 \mathrm{OH}$ progesterone & 33 & 17 & $27 \pm 15$ & $133 \pm 52$ \\
\hline Dehydroepiandrosterone & 25 & 14 & $98 \pm 38$ & $180 \pm 105$ \\
\hline Androstenedione & $<5$ & $<5$ & $36 \pm 16$ & $64 \pm 22$ \\
\hline Cortisol $(\mu g / d l)$ & 1.3 & 2.4 & $8.3 \pm 3.4$ & $27.4 \pm 3.4$ \\
\hline
\end{tabular}

Hormonal studies in the 46XX sister of patient No. 1, done at $7 \mathrm{yr}, 10$ mo of age, after glucocorticoid (but not mineralocorticoid) replacement therapy had been discontinued for $36 \mathrm{~h}$. Basal ACTH concentration, before administration of ACTH, was $400 \mathrm{pg} / \mathrm{ml}$ ( $\mathrm{nl}<100$ $\mathrm{pg} / \mathrm{ml})$. 


\section{Methods}

Preparation and blotting of DNA and RNA. Fibroblasts were cultured from skin obtained at surgery from patient 1 , and peripheral leukocytes were obtained from patient 2. Genomic DNA was prepared from these cells by lysis in $0.32 \mathrm{M}$ sucrose, $10 \mathrm{mM}$ Tris pH 7.5, $5 \mathrm{mM} \mathrm{MgCl}_{2}, 1 \%$ Triton X-100 followed by centrifugation at $2,500 \mathrm{~g}$ for $15 \mathrm{~min}$. The pelleted nuclei were resuspended in $10 \mathrm{mM}$ Tris pH 7.5, $10 \mathrm{mM} \mathrm{NaCl}$, $10 \mathrm{mM}$ EDTA and lysed by adding $\mathrm{NaDodSO}_{4}$ to $1 \%$ and proteinase $\mathrm{K}$ to $0.2 \mathrm{mg} / \mathrm{ml}$. After gentle overnight agitation at $37^{\circ}$ the solution was extracted with phenol, then extracted with chloroform and precipitated with ethanol. The precipitated DNA was harvested by spooling, washed in $70 \%$ ethanol, dried, and dissolved in $10 \mathrm{mM}$ Tris, $1 \mathrm{mM}$ EDTA. Restriction endonuclease digestions, gel electrophoresis, Southern blotting, and autoradiography were as described (30).

Gonadal tissue from patient 1 was frozen in liquid $\mathrm{N}_{2}$ at the time of surgery. RNA was prepared, electrophoresed through agarose gel, transferred to nylon membranes, probed, and autoradiographed as described previously (31). Cloned cDNA probes for human P450 scc (32), adrenodoxin (24), adrenodoxin reductase (17), sterol carrier protein 2 (33), endozepine (34), and hamster GRP-78 (35) were isolated from agarose gel and labeled with ${ }^{32} \mathrm{P}$ by random primer labeling.

Amplification and sequencing of genomic DNA. Samples of genomic DNA were used for enzymatic amplification of the exons of the P450scc gene by polymerase chain reaction (PCR) (36). Each $25-\mu 1$ reaction contained $25 \mathrm{ng}$ of genomic DNA, $10 \mathrm{mM}$ Tris (pH 8.0), 50 $\mathrm{mM} \mathrm{KCl}, 2 \mathrm{mM} \mathrm{MgCl} 2,15 \mu \mathrm{g} / \mathrm{ml} \mathrm{BSA}, 200 \mu \mathrm{M}$ each of dGTP, dATP, dTTP, and dCTP, $0.2 \mu \mathrm{M}$ of each of the two primers used and $1 \mathrm{U} T$. aquaticus (Taq)-DNA polymerase. Amplifications were done in a commercial thermal cycler programmed as follows: $(a)$ initial denaturation at $95^{\circ}$ for 7 min without Taq polymerase; (b) addition of Taq polymerase followed by 40 cycles of denaturing at $94^{\circ}$ for $1 \mathrm{~min}$, annealing at $60^{\circ}$ for $30 \mathrm{~s}$ and extension at $72^{\circ}$ for $90 \mathrm{~s} ;(c)$ final extension at $72^{\circ}$ for $7 \mathrm{~min}$. The sizes of the resulting PCR products were analyzed by electrophoresis in $1 \%$ agarose gel stained with ethidium bromide and photographed under ultraviolet light.

PCR primers were designed to correspond to 18-20 base sequences of introns of the human P450scc gene (27). Where possible, these primers were 10-20 bases from intron/exon junctions to facilitate sequencing these junctions; however, for primers 3 'scc 1 and 5 'scc6, the available sequence data for the introns did not permit this. The sequences of each pair of primers and their distances from the intron/ exon junctions are shown in Table III.

PCR products were extracted with phenol/chloroform and purified by passing through a Centricon-100 filter (Amicon, Beverley, MA). This purified DNA was blunt-ended with Klenow polymerase, phos- phorylated with ATP and T4 polynucleotide kinase and subcloned into pBluescript vectors. DNA sequences were determined from single- or double-stranded vectors by the dideoxynucleotide technique $(37,38)$ using ${ }^{35} \mathrm{~S}$ [dATP] and Sequenase (United States Biochemical Corp., Cleveland, $\mathrm{OH})$.

The sizes of the resulting PCR products are listed in Table III. Oligonucleotide pairs 5 'sccl and $3^{\prime} \mathrm{scc} 1$ through 5 'scc7 and 3 'scc7, respectively, amplified exons 1-7 as small fragments of $135-335 \mathrm{bp}$. These were cloned and completely sequenced on each strand from single reactions. Oligonucleotide pair 5'scc8 and 3'scc9 spanned exons 8 and 9, and intron 8 , resulting in a fragment of $\sim 850 \mathrm{bp}$. This larger fragment was cleaved into two smaller fragments, each containing one exon, with restriction endonuclease Acc I. These two smaller fragments were then subcloned and sequenced on each strand. For both patients, two completely separate enzymatic amplifications were made with all eight pairs of oligonucleotides and the products of all 16 PCR reactions were cloned and completely sequenced on both strands.

Amplification and sequencing of testicular $c D N A$. Testicular RNA from patient No. 1 was used to synthesize complementary DNA (cDNA). Each 20- $\mu$ l reaction contained $1 \mu \mathrm{g}$ of total cellular RNA in 10 $\mathrm{mM}$ Tris $\cdot \mathrm{HCl}(\mathrm{pH} 8.3), 50 \mathrm{mM} \mathrm{KCl}, 5 \mathrm{mM} \mathrm{MgCl}, 1 \mathrm{mM}$ each of dGTP, dATP, dCTP, and dTTP, and $2.5 \mu \mathrm{M}$ of oligodeoxythymidine $\left[(d T)_{17}\right]$. After RNA denaturation at $65^{\circ} \mathrm{C}$ for $2 \mathrm{~min}$ the mixture was chilled rapidly and $1 \mathrm{U}$ recombinant placental RNase inhibitor (Perkin Elmer Cetus, Norwalk, CT) and 2.5 U Moloney murine leukemia virus reverse transcriptase were added. Synthesis of cDNA was initiated by heating to $42^{\circ} \mathrm{C}$ for $1 \mathrm{~h}$ and terminated by heating to $95^{\circ} \mathrm{C}$ for $5 \mathrm{~min}$.

To initiate PCR amplification of the synthesized cDNA, $5 \mu$ l of the above reaction was mixed with $20 \mu \mathrm{l}$ of $70 \mathrm{mM}$ Tris $\mathrm{HCl}(\mathrm{pH} \mathrm{8.0)}, 15$ $\mathrm{mM}\left(\mathrm{NH}_{4}\right)_{2} \mathrm{SO}_{4}, 2 \mathrm{mM} \mathrm{MgCl}, 15 \mu \mathrm{g} / \mathrm{ml} \mathrm{BSA}, 0.2 \mu \mathrm{M}$ of each of the two primers (5'sccl and 3'scc9; Table III) and $1 \mathrm{U}$ Taq polymerase. Amplifications were done in a commercial thermal cycler programmed as for the amplification of genomic DNA (above), except that the extension program in step 2 was for $180 \mathrm{~s}$ rather than $90 \mathrm{~s}$.

\section{Results}

Clinical studies. The diagnosis of a severe salt-wasting form of congenital adrenal hyperplasia in a sibling resulted in early referral and evaluation of patient No. 1 . The patient's lack of clinically significant hyponatremia and hyperkalemia at $2 \mathrm{~d}$ of life followed by development of severe hyponatremia, hyperkalemia, acidosis, and shock by 7-10 d is typical of all forms of salt wasting congenital adrenal hyperplasia $(1,2)$. The minimal basal concentrations of the $\Delta^{5}$ steroids (pregnenolone, $170 \mathrm{H}$ -

Table III. Oligonucleotide Primers Used for PCR Amplification

\begin{tabular}{|c|c|c|c|c|c|}
\hline Name & Sense primers & Exons amplified & Antisense primer & Name & $\begin{array}{l}\text { Size } \\
\text { (bp) }\end{array}$ \\
\hline 5 SCC1 & 5-GCTGAAGTGGAGCAGGTACA-3' (20) & EXON 1 & ( 3) 5'-TCCCACCCTCTGCCAGGCT-3' & $3 \cdot S C C 1$ & 334 \\
\hline $5 ' S C C 2$ & 5'-TCCTTCCATCAGCCCCTCTC-3' (14) & EXON 2 & (11) 5'-CCAGTCCCTGGGAGATGGC-3' & $3 ' \mathrm{SCC}_{2}$ & 221 \\
\hline 5 'SCC3 & 5'-GGTCTGTGACCATGAGGGCT-3' (21) & EXON 3 & (10) 5'-CACTGCCAGCCAGGTGCAA-3' & $3 \operatorname{scc} 3$ & 270 \\
\hline $5 ' S C C 4$ & 5'-CGTCAGAAATGGCTCCTCAG-3' (19) & EXON 4 & (40) 5'-AGGAGCCGGCTGAGGCCT-3' & $3 \cdot S C C 4$ & 301 \\
\hline 5 SCC5 & 5'-CTGCAGGGAACCTCACTCTT-3' (23) & EXON 5 & ( 7) 5'-GGTGCCGCCCCTACAGCC-3' & 3'scc5 & 229 \\
\hline 5'SCC6 & 5'-ATACCCTACTCCCCACCAG-3' (0) & EXON 6 & (30) 5'-CCTGCCCAGGGATTGGAGT-3' & 3'scC6 & 235 \\
\hline 5 SCC7 & 5'-CCATCAGCTTCTGAGGTCCC-3' (11) & EXON 7 & ( 6) 5'-CTGCAGCCTGCTGGCTGC-3' & $3 ' S C C 7$ & 135 \\
\hline 5 'SCC8 & 5'-GCTTACTCAGGCCTCTGATC-3' (12) & EXON 8 \& EXON 9 & (12) 5-CTCCCATGTGGCTGCAGGC-3' & 3'scc9 & -850 \\
\hline
\end{tabular}

Numbers in parenthesis show the number of bases of intron DNA between the primer and the corresponding exon. 
pregnenolone, and dehydroepiandrosterone) and their failure to rise in response to tropic hormonal stimulation rule out the diagnosis of $3 \beta$ hydroxysteroid dehydrogenase deficiency that had been made (incorrectly) in the sibling. The elevated basal concentration of ACTH and the minimal concentrations of all adrenal and gonadal steroids and their unresponsiveness to stimulation with ACTH and hCG, respectively, establish the diagnosis of congenital lipoid adrenal hyperplasia. The measurement of steroid values that are greater than zero does not necessarily mean a "partial enzyme deficiency." Some of the steroids measured at 2-10 d of age represent residual maternal steroids (6), as shown by the lower values, even after tropic stimulation, at 3-4 wk of age (Table I). Furthermore, extraadrenal and extragonadal steroidogenesis do occur, especially in the fetus $(39,40)$; however, this peripheral steroidogenesis is mediated by enzymes other than those found in the adrenals and gonad (41-43). Thus, the hormonal data unambiguously establish a defect in the synthesis of pregnenolone and all other steroid hormones. This has, to date, been interpreted as a lesion in P450scc $(1,6,9,12,25)$. Similarly, the studies in the 7-yr, 10-mo-old sister suggest the presence of low concentrations of some adrenal steroids while other steroids, such as progesterone and androstenedione, were undetectable. However, these minimal steroid concentrations did not rise in response to ACTH (Table II). These values probably reflect immunocrossreactivity and/or peripheral metabolism of the replacement steroids administered.

DNA blotting studies. To determine if gross deletions, conversions, or rearrangements of the P450scc gene caused lipoid $\mathrm{CAH}$, genomic DNA from patients 1 and 2 and from a normal individual were digested with the restriction endonucleases Bam HI, Hind III, and Eco RI. Southern blots of these DNAs were probed with a full-length human P450scc cDNA. Fig. 1 shows that the pattern of P450scc gene fragments identified was identical among the three DNA samples with each of the endonucleases used. Bam $\mathrm{HI}$ yielded fragments of 1.3, 4.8, 5.2, and $12 \mathrm{~kb}$; Hind III yielded fragments of 5.8 and $23 \mathrm{~kb}$, and Eco RI yielded fragments of $6.0,6.6,8.5 \mathrm{~kb}$. These patterns closely match the P450scc gene mapping and sequencing data of Morahashi et al. (27) (Fig. 1). Thus, the identity of the patterns from patients and a control, and their correspondence with the established map of this locus indicate that gross deletions, duplications, or rearrangements have not occurred in the P450scc genes of these patients with lipoid CAH.

PCR amplification and sequencing of genomic DNA. To determine if point mutations or very small deletions, duplica-

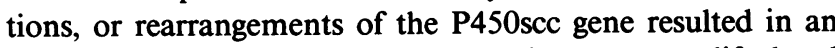
abnormal P450scc mRNA in these patients, we amplified and sequenced the exons of their P450scc genes. Because the $\mathrm{P} 450 \mathrm{scc}$ gene is $\sim 15-20 \mathrm{~kb}$ long (27), the entire gene cannot be manipulated or sequenced easily. Therefore, we designed eight pairs of oligonucleotides that spanned the nine exons (Table III), permitting the enzymatic amplification and sequencing of all of the portions of the P450scc gene that encode the P450scc protein as eight discrete fragments of 135 to $\sim 850$ bases.

The sequencing was done a total of four times from independent amplifications, and any ambiguities were resequenced. No abnormalities in the P450scc gene in either patient. The sequences of the exons were consistent with the P450scc cDNA (32) and the sequences at the intron/exon boundaries were consistent with the human P450scc gene se-
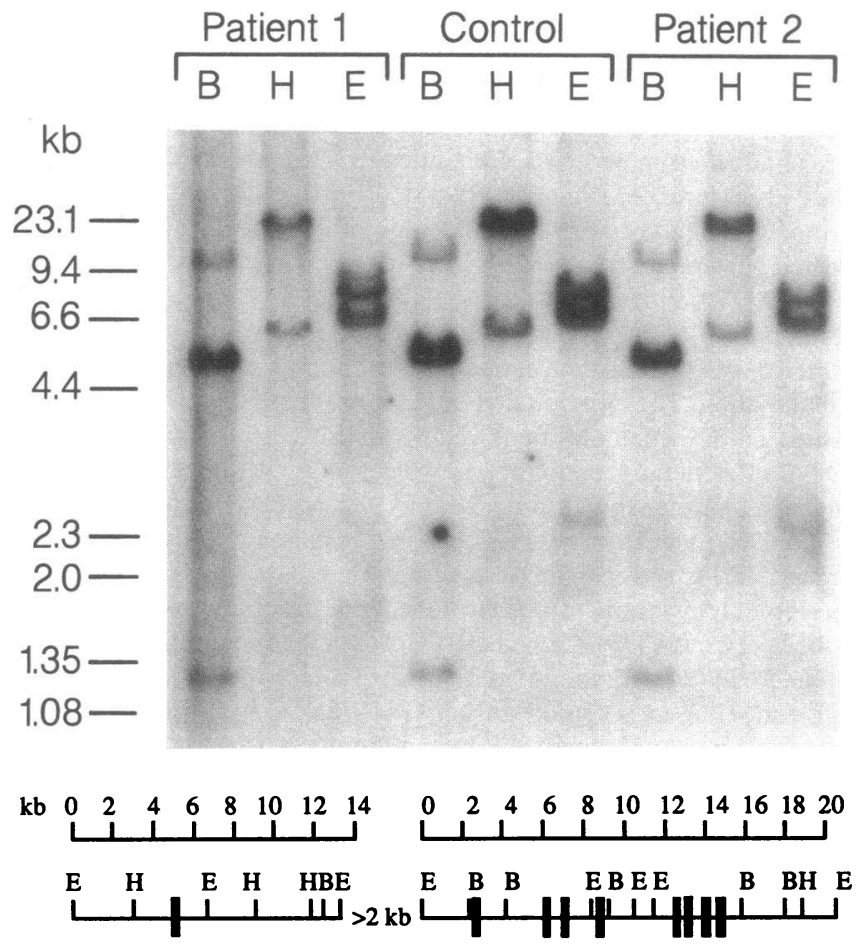

Figure 1. (Top) Southern blot. Genomic DNA was prepared from patients 1 and 2 and from a normal control. The DNA was digested with Bam HI (B), Hind III (H), or Eco RI (E) and displayed by electrophoresis through $1 \%$ agarose gel. The DNA fragments were transferred to a nylon membrane and probed with ${ }^{32} \mathrm{P}$-labeled full-length human P450scc cDNA (32). Molecular size markers in kilobases (kb) shown at left were determined by the electrophoretic migration of non radioactive bacteriophage $\lambda$ DNA cut with Hind III and bacteriophage $\phi \times 174$ DNA cut with Hae III run in another lane and seen by staining with ethidium bromide. (Bottom) Map of the human P450scc gene as indicated by the sequencing studies of Morohashi et al. (27) and confirmed by the Southern blotting data shown in the upper panel. Mapped DNA is indicated by a solid bar with the exons indicated as superimposed rectangles. A region of at least $2 \mathrm{~kb}$ in the first intron has not been mapped, hence, the gene is shown as two noncontiguous segments. Note the scale in kb. Restriction endonuclease cleavage sites indicated are Bam HI $(B)$, Hind III $(H)$, and Eco $\mathrm{RI}(E)$.

quence (27). The only minor variations with those sequences were as follows. First, both of our patients and the human P450scc cDNA show the sequence GCATG, where ATG is the translational initiation signal in exon 1; by contrast Morohashi et al. (27) reported GCAATG. As our two patient genes and the cDNA agree, it is likely that the additional A residue is a sequencing error by Morohashi et al. (27). Second, both of our patients and the gene sequence of Morohashi et al. (27) show TGC (encoding cysteine) and ATC (encoding isoleucine) at codons No. 16 and No. 301, respectively. By contrast, the cDNA sequence of Chung et al. (32) shows TAC (tyrosine) and ATG (methionine) at codons 16 and 301, respectively, suggesting errors in the reverse transcriptase reaction or sequencing errors by Chung et al. (32). Third, at codon No. 274 in exon 4 both of our patients and the human P450scc cDNA show TTC (encoding phenylalanine) whereas Morohashi et al. (27) reported TTG (leucine). As the bovine sequence also has TTC (Phe) at this location and because Phe residues are generally 
conserved, this suggests a sequencing error by Morohashi et al. (27). Finally, at codon No. 452 in exon 8, the previously published cDNA (32), the gene (27) and patient No. 1 have AAC (asparagine), whereas patient No. 2 had AAT (asparagine). As the amino acid is unchanged the nucleotide difference is inconsequential. Thus, both patients have P450scc genes capable of encoding P450scc mRNA and protein that are absolutely normal.

$P C R$ amplification and sequencing of $c D N A$. To rule out undetected compound heterozygosity or RNA splicing errors, we confirmed the results from PCR of genomic DNA by PCR amplification and sequencing of P450scc cDNA. As PCR oligonucleotides $5^{\prime} \operatorname{scc} 1$ and $3^{\prime}$ scc9 lie in the $5^{\prime}$ and $3^{\prime}$ untranslated regions of P450scc mRNA, we used them to amplify the protein-coding region of P450scc cDNA synthesized by oligo $(d T)$-primed reverse transcription of testicular RNA from patient No. 1. The resulting 1,637-bp PCR cDNA product (Fig. 2 ), including the 20-base primers on each end, was sequenced on both strands.

Because enzymatic errors in reverse transcription and, more commonly, in PCR amplification with Taq polymerase occur fairly commonly, we performed three separate cDNA syntheses, PCR amplifications, cloning, and complete cDNA sequencing. The first PCR/cDNA examined showed a change in codon No. 184 from AGG (arginine) to AAG (lysine). The second PCR/cDNA examined showed a change in codon No. 314 from GAG (glutamic acid) to GGG (glycine). The third PCR/cDNA examined was completely normal in these two regions, i.e., identical with the published CDNA (32) and gene (27) sequences, indicating that at least one and probably both of the changes are PCR artifacts. Thus, at least one allele in

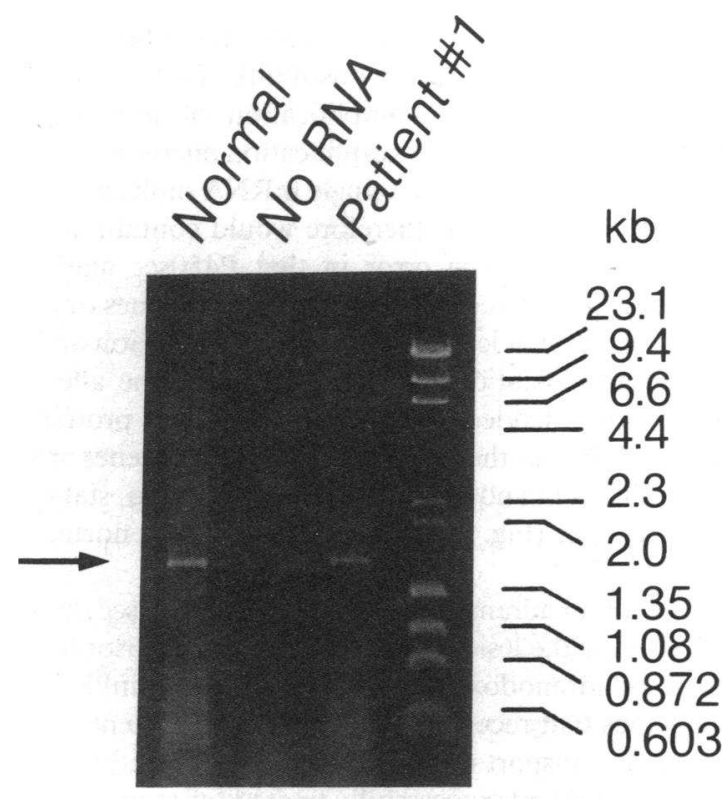

Figure 2. Agarose gel of PCR-amplified P450scc cDNA. The left lane shows the PCR-amplified 1,637 bp P450scc cDNA from a sample of RNA from a normal human fetal adrenal; the middle lane shows a control reaction with no RNA, and the right hand lane shows the products of the PCR amplification of P450scc cDNA from the testicular RNA of patient No. 1. The molecular size markers, shown on the right, are bacteriophage $\lambda$ DNA cut with Hind III and bacteriophage $\phi \times 174$ cut with Hae III. The gel was stained with ethidium bromide and photographed under ultraviolet light. patient No. 1 was making P450scc mRNA encoding normal $\mathrm{P} 450$ scc protein. Since reverse transcriptase and/or Taq polymerase errors occur about every 1-2,000 bases, finding PCR errors in these cDNA clones is to be expected. The finding of normal sequences for codons 184 and 314 in the four genomic PCR amplifications is strongly consistent with this, and suggests that both P450scc alleles are normal in these patients.

$R N A$ blotting studies. It remained possible that the congenital lipoid adrenal hyperplasia in these patients could be caused by a lesion in the promoter of the P450scc gene. In such a hypothetical case, the gene might be anatomically intact but transcriptionally inactive. In principle, this could be examined by sequencing the regulatory regions of the DNA. However, this would require a very precise knowledge of which bases are responsible for activity - a knowledge not yet available. Furthermore, we have recently established that sequences as far upstream as 2,300 bases from the transcriptional start site are involved in the transcriptional regulation of the human P450scc gene (31). Thus sequencing is not a useful approach for unknown promoter lesions.

To determine if the P450scc gene in patient No. 1 was able to make P450scc mRNA, we analyzed testicular RNA by Northern blotting analysis. As the patient's surgery was done at $6.5 \mathrm{mo}$ of age, an age at which testicular steroidogenesis is normally diminishing, the patient was given 5,000 $\mathrm{U}$ of hCG 3 $\mathrm{d}$ before surgery. As seen in Fig. $3 A$, a band of P450scc mRNA was readily detectable in the RNA from the patient's testis. This band is identified as P450scc mRNA by its comigration at the expected $2.0-\mathrm{kb}$ size with P450scc mRNA from a control RNA sample (from the testis of a 20-wk gestation fetus) and by its intense hybridization under highly stringent hybridization and washing conditions. Thus the promoter of the P450scc gene in patient No. 1 was able to direct the synthesis of P450 scc mRNA, and, as shown by the sequencing studies, that P450scc mRNA was completely normal.

As it has been deduced, but not experimentally proven, that a lesion in adrenodoxin reductase or adrenodoxin would have more devastating and widely ranging manifestations than those seen in lipoid CAH, we then examined these $\mathrm{mRNAs}$ in patient No. 1. We removed the $\mathrm{P} 450 \mathrm{scc}$ probe from the northern blot in Fig. $3 A$ by boiling (and repeating the autoradiography to show that no residual ${ }^{32} \mathrm{P}$ remained on the membrane), then reprobed the blot with ${ }^{32} \mathrm{P}$-labeled cDNA for adrenodoxin (Fig. $3 B$ ). This procedure was then repeated and the blot reprobed for adrenodoxin reductase (Fig. $3 C$ ). The mRNA from the patient's testis had mRNAs for adrenodoxin and adrenodoxin reductase, as expected. Each of these mRNAs comigrated with the corresponding mRNA in the control tissue, and each mRNA hybridized under highly stringent conditions, indicating the presence of normal-sized mRNA. Because the control was tissue from a 20-wk fetus, quantitative comparisons of the abundance of each mRNA in the patient's tissue and the control should not be made. While the hybridization pattern in Fig. $3 B$ might suggest a relative diminution in the patient's adrenodoxin mRNA abundance, this would have little effect on P450scc activity as it is binding of cholesterol to P450scc, rather than electron transport, that is rate-limiting in P450scc activity.

Because the sequencing and RNA blotting studies appear to rule out a lesion in the cholesterol side-chain cleavage system as the cause of lipoid CAH, we considered other possible explanations. Disorders of cholesterol synthesis, binding to serum 


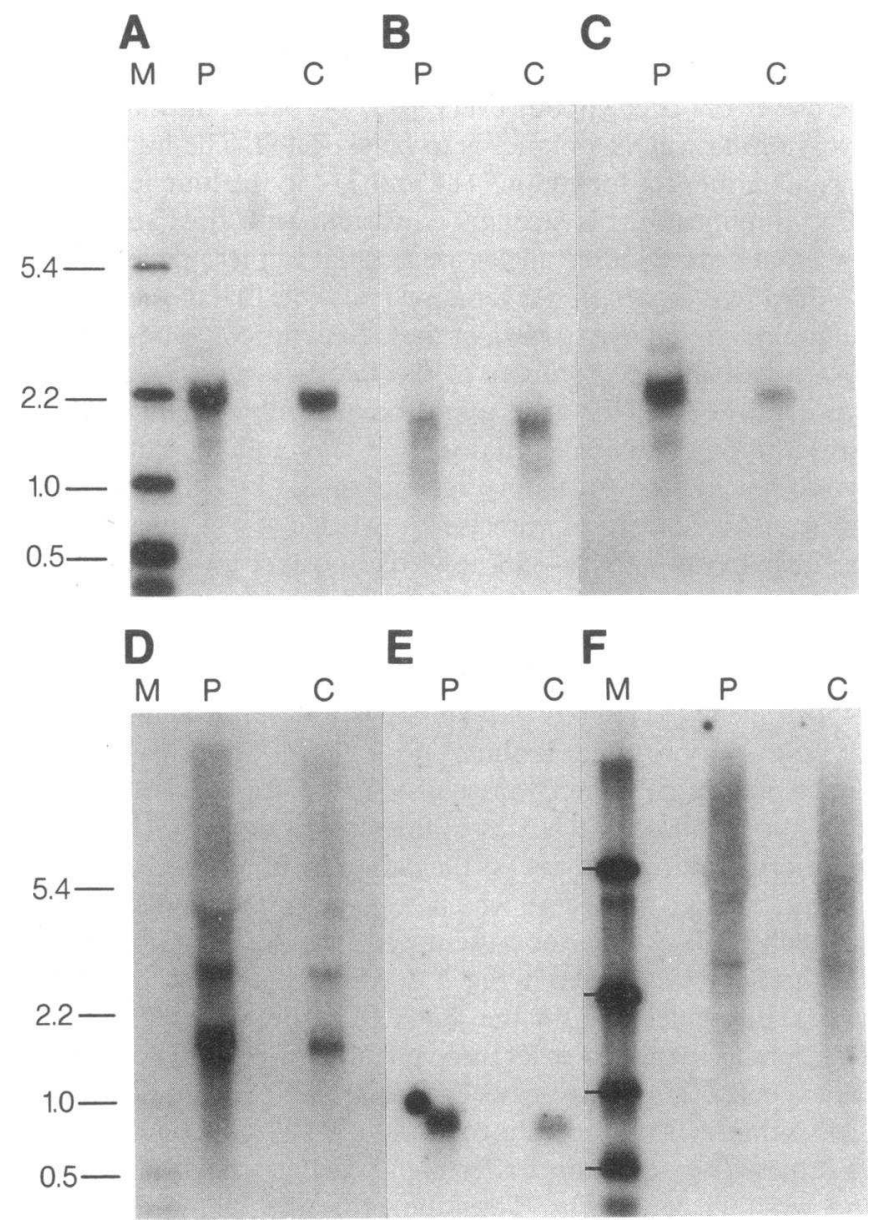

Figure 3. Northern blots. RNA was prepared from testicular tissue removed from patient No. $1(P)$ and from control testicular tissue from a normal 20-wk-gestation human fetus $(C)$, obtained from the International Institute for the Advancement of Medicine (Philadelphia, PA). Molecular size markers $(M)$ are DNA from bacteriophage PM2 cleaved with Hind III and end-labeled by treatment with alkaline phosphatase followed by treatment with polynucleotide kinase and $\gamma-{ }^{32} \mathrm{P}$ ATP (sizes are in $\left.\mathrm{kb}\right) .(A-E)$ show the same blot wherein the patient's sample consisted of $25 \mu \mathrm{g}$ of total RNA and the control sample consisted of $10 \mu \mathrm{g}$ of total RNA. In each case the blot was autoradiographed then washed and reautoradiographed to ensure that no radioactive signal remained before the blot was reprobed. $(F) \mathrm{Au}$ toradiography of a separate blot containing $20 \mu \mathrm{g}$ of RNA from the patient and the control in each lane. The human cDNA probes used were $(A) \mathrm{P} 450$ scc, $(B)$ adrenodoxin, $(C)$ adrenodoxin reductase, $(D)$ sterol carrier protein 2, $(E)$ endozepine, $(F)$ hamster GRP-78.

LDL, and receptor-mediated uptake of LDL cholesterol are known causes of other diseases. However, recent data suggest that steroidogenic tissues employ specialized factors to store and mobilize cholesterol. Disorder of any such factor could conceivably cause the syndrome of lipoid CAH. At present, compelling data involve at least three proteins in the activation of the cholesterol side-chain cleavage process: sterol carrier protein $2(44-46)$, endozepine $(47,48)$, and steroidogenesis activator peptide $(49,50)$, which is the carboxy-terminal 30 amino acids of glucose-regulated protein (51). Therefore, we reprobed the Northern blot of testicular RNA from patient No. 1 with probes for each of these factors. As shown in Fig. 3, $D-F$, the mRNAs for these proteins were also present in normal size in the patient's tissue. Thus, we have found neither a lesion in the P450scc system, nor in the known intracellular activators of steroidogenesis.

\section{Discussion}

The diagnosis of lipoid CAH is inherently indirect because, in contrast to other forms of $\mathrm{CAH}$, there is no characteristic accumulation of a precursor steroid. Because no pregnenolone is made, this disorder was previously thought to involve P450scc, the enzyme converting cholesterol to pregnenolone. The failure of adrenal or gonadal mitochondria from such patients to convert cholesterol to pregnenolone appeared to confirm this view (6-9). We previously examined the P450scc genes of three patients with lipoid CAH by Southern blotting analysis, and found no gross lesions (26). However, because that study was not done with a full-length cDNA, gross lesions at the 5 ' end of the gene could have been missed. Furthermore, such gross lesions are much less common than are point mutations, which can only be detected by sequencing. PCR technology has now permitted a detailed search for possible mutations in the P450scc gene associated with lipoid CAH. No such lesion was found in the genomic DNA of two patients.

PCR amplification, cloning, and sequencing of a large gene in multiple segments can miss lesions in introns, causing RNA splicing errors, or might miss the lesions in compound heterozygotes. The chances of not detecting a lesion in a compound heterozygote would be $1 / x(1 / 2)^{n}$, where $x$ is the total number of lesions on both alleles and $n$ is the number of independent clones examined from separate PCR amplifications. For a compound heterozygote having one lesion on each allele examined in four separate PCR amplifications as we did, the probability of missing all lesions is $1 / 32$ or $3.125 \%$. To reduce this possibility to zero, and to exclude the possibility of RNA splicing errors, we performed PCR amplification of testicular cDNA from patient No. 1. As this amplification encompassed the entire protein-coding region of a single mRNA molecule, it arose from only one allele, and therefore would contain any missense mutation or splicing error in that P450scc allele. Complete sequencing of three independent cDNA clones only showed random artifactual lesions of reverse transcription and Taq polymerase amplification. Therefore, at least one allele (and probably both) encoded mRNA with a normal protein coding sequence. Thus, in these patients the $\mathrm{P} 450 \mathrm{scc}$ genes are grossly intact (Fig. 1), and can be transcribed into stable mRNA of normal size (Fig. 3) that has a completely normal coding sequence.

If congenital lipoid adrenal hyperplasia is not P450scc deficiency, what, then, is the lesion? As discussed above, disorders in adrenodoxin or adrenodoxin reductase seem most unlikely. The other enzymes that receive their reducing equivalents via these two electron transport intermediates are apparently normal in lipoid CAH patients successfully treated for many years $(5,6)$. Furthermore, the mRNAs for both of these proteins were present in the testicular tissue from patient No. 1. A more promising area may be the steps proximal to P450scc. Cholesterol is stored as cholesterol esters in lipid droplets in steroidogenic tissues. A defect in cholesterol esterase causes a disorder of steroidogenesis similar to lipoid CAH. However, this disorder, Wollman's disease, affects all tissues, leads to hepatosplenomegaly and characteristic foam cells in the marrow, and 
is inevitably fatal in the first year of life irrespective of adrenal replacement therapy (52). Thus, a candidate step for congenital lipoid adrenal hyperplasia should occur after cholesterol esters are converted to free cholesterol (and before P450scc) and should be specific to steroidogenic tissues. As only the steroidogenic tissues need to transport large amounts of cholesterol into mitochondria, the factors involved in this transport might be attractive candidates. Sterol carrier protein 2, a cytoplasmic cholesterol-binding protein, is one of several factors involved in the flow of cholesterol to the inner mitochondrial membrane (44-46). Whereas its mRNA is present in patient No. 1, its sequence in patient No. 1 is unknown. However, because SCP 2 also is found in the liver, this does not appear to be a strong candidate to be the affected step in lipoid CAH. Endozepine, an endogenous protein that binds to the benzodiazepine receptor, has recently been implicated in the transport of cholesterol across the outer mitochondrial membrane $(47,48)$. However, this protein is also expressed ubiquitously (34) and hence does not fulfill the criterion of specificity to steroidogenic tissues. Furthermore, its mRNA was also present in the testis of patient No. 1. Finally, Pederson and Brownie $(49,50)$ have reported the isolation and sequencing of a 30 -amino acid steroidogenesis activator peptide (SAP) that appears to function in the flux of cholesterol across the inner mitochondrial membrane. Recent studies show that SAP is the carboxy-terminal 30 amino acids of a widely expressed heat shock protein, HSP-78 (also termed GRP-78) (51). This protein is also widely (if not ubiquitously) expressed. GRP-78 mRNA was also present in the testis of patient No. 1. Thus the molecular defect in congenital lipoid adrenal hyperplasia remains unknown.

In the absence of a defined molecular lesion, congenital lipoid adrenal hyperplasia remains a syndrome. It is possible that some patients will be found with P450scc gene lesions, and that such patients will have phenotypic and clinical manifestations of lipoid $\mathrm{CAH}$ that are indistinguishable from the disease in these two patients. Although lipoid CAH is rare, it appears in genetic clusters. Among the 32 cases compiled by Hauffa et al. (6) $18(56 \%)$, including patient No. 2 in this study, were of Japanese heritage and another $5(16 \%)$ were from Southern Germany or Switzerland. Patient No. 1, newly described in this report, is of Korean ancestry. As Japan and Korea are very close geographically and historically, patients 1 and 2 may represent the same gene pool. However, we have recently done one set of genomic PCR amplifications of the P450scc exons from a patient of Mexican Indian ancestry and again found normal sequences. Examination of the P450scc genes from European and other patients with lipoid CAH will be of interest.

In addition to finding normal $\mathrm{P} 450 \mathrm{scc}$ gene sequences and the normal mRNAs discussed above, any future molecular model of congenital lipoid adrenal hyperplasia must also account for the following features of the disorder that are difficult to reconcile with a P450scc gene lesion. First, while the lesion in the adrenals and gonads is steroidogenically equivalent, only the adrenals accumulate cholesterol and cholesterol esters; even though fetal Leydig cells should be very active in steroidogenesis, they do not accumulate lipids like the adrenals. Second, the successful gestation of these patients as normal term infants suggests that placental synthesis of pregnenolone and progesterone should be intact, although the role of transplacental maternal progesterone has not been elucidated. Thus, a molecular model of lipoid CAH should implicate a gene involved in adrenal and gonadal, but not in placental steroidogenesis.

\section{Acknowledgments}

We thank Dr. Jerome F. Strauss III (Dept. of OB/GYN, University of Pennsylvania) for the SCP-2 plasmid, Dr. Amy S. Lee (Dept. of Biochemistry, University of Southern California) for the GRP-78 plasmid, and Dr. Anthony Purchio (Oncogen Inc., Seattle, WA) for the endozepine plasmid, and Dr. Songja Pang (Northwestern University, Chicago, IL) for the DNA from the patient of Mexican Indian ancestry.

Supported by National Institutes of Health grants DK 37922 and DK 42154 and March of Dimes Clinical Grant 6-396, all to W. L. Miller.

\section{References}

1. Miller, W. L., and L. S. Levine. 1987. Molecular and clinical advances in congenital adrenal hyperplasia. J. Pediatr. 111:1-17.

2. Miller, W. L. 1991. The adrenal cortex. In Pediatrics. A. M. Rudolph, J. I. E. Hoffman, and C. R. Rudolph, editors. Appleton \& Lange, East Norwalk, CT. 1584-1613.

3. Sandison, A. T. 1955. A form of lipidosis of the adrenal cortex in an infant. Arch. Dis. Child. 30:538-541.

4. Prader, A., and R. E. Siebenmann. 1957. Nebennireninsuffizienz bei kongenitaler Lipoidhyperplasie der Nebennieren. Helv. Paediatr. Acta. 12:569-595.

5. Kirkland, R. T., J. L. Kirkland, C. M. Johnson, M. G. Horning, L. Librik, and G. W. Clayton. 1973. Congenital lipoid adrenal hyperplasia in an eight-yearold phenotypic female. J. Clin. Endocrinol. \& Metab. 36:488-496.

6. Hauffa, B., W. L. Miller, M. M. Grumbach, F. A. Conte, and S. L. Kaplan. 1985. Congenital adrenal hyperplasia due to deficient cholesterol side-chain cleavage activity $(20,22$ desmolase $)$ in a patient treated for 18 years. Clin. Endocrinol. 23:481-493.

7. Camacho, A. M., A. Kowarski, C. J. Migeon, and A. J. Brough. 1968. Congenital adrenal hyperplasia due to a deficiency of one of the enzymes involved in the biosynthesis of pregnenolone. J. Clin. Endocrinol. \& Metab. 28:153-161.

8. Degenhart, H. J., K. H. A. Visser, H. Boon, and N. J. D. O'Doherty. 1972. Evidence for deficiency $20 \alpha$ cholesterol hydroxylase activity in adrenal tissue of a patient with lipoid adrenal hyperplasia. Acta Endocrinologia. 71:512-518.

9. Koizumi, S., S. Kyoya, T. Miyawaki, H. Kidani, T. Funabashi, H. Nakashima, Y. Nakanuma, G. Ohta, E. Itagaki, and M. Kattagiri. 1977. Cholesterol side-chain cleavage enzyme activity and cytochrome P450 content in adrenal mitochondria of a patient with congenital lipoid adrenal hyperplasia (Prader disease). Clin. Chim. Acta. 77:301-306.

10. Simpson, E. R. 1979. Cholesterol side-chain cleavage, cytochrome P450, and the control of steroidogenesis. Mol. Cell. Endocrinol. 13:213-227.

11. Kimura, T. 1981. ACTH stimulation on cholesterol side chain cleavage activity of adrenocortical mitochondria. Mol. Cell. Biochem. 36:105-112.

12. Miller, W. L. 1988. Molecular biology of steroid hormone synthesis. Endocr. Rev. 9:295-318.

13. Cupp, J. R., and L. E. Vickery. 1988. Identification of free and $\left[\mathrm{Fe}_{2} \mathrm{~S}_{2}\right]-$ bound cystine residues of adrenodoxin. J. Biol. Chem. 263:17418-17421.

14. Wikvall, K. 1984. Hydroxylations in biosynthesis of bile acids: isolation of a cytochrome $\mathrm{P}-450$ from rabbit liver mitochondria catalyzing 26-hydroxylation of C-27 steroids. J. Biol. Chem. 259:3800-3804.

15. Su, P., H. Rennert, R. M. Shayiq, R. Yamamoto, Y. Zheng S. Addya, J. F. Strauss III, and N. G. Avadhani. 1990. A cDNA encoding a rat mitochondrial cytochrome P450 catalyzing both the 26-hydroxylations of cholesterol and the 25-hydroxylation of vitamin $D_{3}$ : gonadotropic regulation of the cognate mRNA in ovaries. DNA Cell Biol. 9:657-665.

16. Björkhem, I., I. Holmberg, H. Oftebro, and J. I. Pedersen. 1980. Properties of a reconstituted vitamin $\mathrm{D}_{3} 25$-hydroxylase from rat liver mitochondria. J. Biol. Chem. 255:5244-5249.

17. Solish, S. B., J. Picado-Leonard, Y. Morel, R. W. Kuhn, T. K. Mohandas, I. Hanukoglu, and W. L. Miller. 1988. Human adrenodoxin reductase: two mRNAs encoded by a single gene on chromosome 17 cen $\rightarrow \mathrm{q} 25$ are expressed in steroidogenic tissues. Proc. Natl. Acad. Sci. USA. 85:7104-7108.

18. Lin, D., Y. Shi, and W. L. Miller. 1990. Cloning and sequence of the human adrenodoxin reductase gene. Proc. Natl. Acad. Sci. USA. 87:8516-8520.

19. Sparkes, R. S., I. Klisak, and W. L. Miller. 1991. Regional mapping of genes encoding human steroidogenic enzymes: P450scc to 15q23-q24; adrenodoxin to 11q22; adrenodoxin reductase to $17 \mathrm{q} 24-\mathrm{q} 25$; and $\mathrm{P} 450 \mathrm{c} 17$ to $10 \mathrm{q} 24-$ q25. DNA Cell Biol. 10:359-365.

20. Brentano, S. T., J. K. Harikrishna, D. Lin, and W. L. Miller. 1991. Biphasic induction of the adrenotoxin reductase gene by forskolin and tissue distribution of its alternately spliced mRNA. In Abstracts of the 73rd Annual Meeting of the Endocrine Society, Washington, DC. Abstr. 1121, p. 311.

21. Chang, C.-Y., D.-A. Wu, C.-C. Lai, W. L. Miller, and B. Chung. 1988. Cloning and structure of the human adrenodoxin gene. DNA (NY). 7:609-615. 
22. Chang, C., D. Wu, T. K. Mohandas, and B. Chung. 1990. Structure, sequence, chromosomal location and evolution of the human ferredoxin gene family. DNA Cell Biol. 9:205-212.

23. Morel, Y., J. Picado-Leonard, D.-A. Wu, C. Chang, T. K. Mohandas, B. Chung, and W. L. Miller. 1988. Assignment of the functional gene for adrenodoxin to chromosome $11 \mathrm{q} 13 \rightarrow$ qter and of two adrenodoxin pseudogenes to chromosome 20cen $\rightarrow$ q13.1. Am. J. Hum. Genet. 43:52-59.

24. Picado-Leonard, J., R. Voutilainen, L. Kao, B. Chung, J. F. Strauss, III, and W. L. Miller. 1988. Human adrenodoxin: cloning of three cDNAs and cycloheximide enhancement in JEG-3 cells. J. Biol. Chem. 263:3240-3244.

25. New, M. I., P. C. White, S. Pang, B. Dupont, and P. W. Speiser. 1989. The adrenal hyperplasias. In The Metabolic Basis of Inherited Disease. 6th ed. C. R. Scriver, A. L. Beaudet, W. S. Sly, and D. Valle, editor. McGraw-Hill Book Co., New York. 1881-1917.

26. Matteson, K. J., B. Chung, M. S. Urdea, and W. L. Miller. 1986. Study of cholesterol side-chain cleavage $(20,22$ desmolase $)$ deficiency causing congenital lipoid adrenal hyperplasia using bovine-sequence P450scc oligodeoxyribonucleotide probes. Endocrinology. 118:1296-1305.

27. Morohashi, K., S. Kogawa, T. Omura, and Y. Fujii-Kuriyama. 1987. Gene structure of human cytochrome P-450(SCC), cholesterol desmolase. J. Biochem. 101:879-887.

28. Saenger, P. 1984. Abnormal sex differentiation. J. Pediatr. 104:1-17.

29. Miller, W. L. 1990. Immunoassays for human Mullerian inhibiting factor: new insights into the physiology of MIF. J. Clin. Endocrinol \& Metab. 70:8-10.

30. Morel, Y., M. David, M. G. Forest, H. Betuel, G. Hauptman, J. Andre, J. Bertrand, and W. L. Miller. 1989. Gene conversions and rearrangements cause discordance between inheritance of forms of 21-hydroxylase deficiency and HLA types. J. Clin. Endocrinol. \& Metab. 68:592-599.

31. Moore, C. C. D., S. T. Brentano, and W. L. Miller. 1990. Human P450scc gene transcription is induced by cyclic AMP and repressed by $12-O$-tetradecanolylphorbol-13-acetate and A23187 by independent cis-elements. Mol. Cell. Biol. 10:6013-6023.

32. Chung, B., K. J. Matteson, R. Voutilainen, T. K. Mohandas, and W. L. Miller. 1986. Human cholesterol side-chain cleavage enzyme, P450scc: cDNA cloning, assignment of the gene to chromosome 15, and expression in the placenta. Proc. Natl. Acad. Sci. USA. 83:8962-8966.

33. Yamamoto, R., C. B. Calen, G. O. Babalola, H. Rennert, J. T. Bilheimer, and J. F. Strauss III. 1991. Cloning and expression of a cDNA encoding human sterol carrier protein 2. Proc. Natl. Acad. Sci. USA. 88:463-467.

34. Webb, N. R., T. Rose, N. Malik, H. Marquardt, M. Shoyab, G. J. Todaro, and D. C. Lee. 1987. Bovine and human CDNA sequences encoding a putative benzodiazepine receptor ligand. DNA (NY). 6:71-79.

35. Lee, A. S., A. Delegeane, and D. Scharff. 1981. Highly conserved glucoseregulated protein in hamster and chicken cells: preliminary characterization of its cDNA clone. Proc. Natl. Acad. Sci. USA. 78:4922-4925.

36. Saiki, R., S. Charf, F. Faloona, K. Mullis, G. Horn, H. A. Ehrlich, and N. Arnheim. 1985. Enzymatic amplification of $\beta$-globin genomic sequences and restriction site analysis for diagnosis of sickle cell anemia. Science (Wash. DC). 230:1350-1353.
37. Sanger, F., S. Nicklen, and A. R. Coulson. 1977. DNA sequencing with chain-terminating inhibitors. Proc. Natl. Acad. Sci. USA. 74:5463-5467.

38. Chen, E. Y., and P. H. Seeburg. 1985. Supercoil sequencing: a fast and simple method for sequencing plasmid DNA. DNA (NY). 4:165-170.

39. Casey, M. L., and P. C. MacDonald. 1982. Extraadrenal formation of a mineralocorticoid: deoxycorticosterone and deoxycorticosterone sulfate biosynthesis and metabolism. Endocr. Rev. 3:396-403.

40. Casey, M. L., C. A. Winkel, and P. C. MacDonald. 1983. Conversion of progesterone to deoxycorticosterone in the human fetus: steroid 21-hydroxylase activity in human tissues. J. Steroid Biochem. 18:449-452.

41. Mellon, S. H., and W. L. Miller. 1989. Extra-adrenal steroid 21-hydroxylation is not mediated by P450c21. J. Clin. Invest. 84:1497-1502.

42. Miller, W. L. 1989. Regulation of mRNAs for human steroidogenic enzymes. Endocrin. Res. 15:1-16.

43. Mellon, S. H., and C. F. Deschepper. 1991. Neurosteroids are not synthesized by adrenal steroidogenic enzymes. In Abstracts of the 73rd Annual Meeting of the Endocrine Society, Washington, DC. Abstr. 1606, p. 432.

44. Chanderbhan, R., B. J. Noland, T. J. Scallen, and G. V. Vahouny, 1982 Sterol carrier protein 2: delivery of cholesterol from adrenal lipid droplets to mitochondria for pregnenolone synthesis. J. Biol. Chem. 257:8928-8934.

45. Vahouny, G. V., R. Chanderbhan, B. J. Noland, D. Irwin, P. Dennis, J. D Labmeth, and T. J. Scallen. 1983. Sterol carrier protein 2: identification of adrenal sterol carrier protein 2 and site of action for mitochondrial cholesterol utilization. J. Biol. Chem. 258:11731-11737.

46. Xu, T., E. P. Bowman, D. B. Glass, and J. D. Labmeth. 1991. Stimulation of adrenal mitochondrial cholesterol side-chain cleavage by GTP, steroidogenesis activator peptide (SAP) and sterol carrier protein-2: GTP and SAP act synergistically. J. Biol. Chem. In press.

47. Yanagibashi, K., Y. Ohno, M. Kawamura, and P. F. Hall. 1988. The regulation of intracellular transport of cholesterol in bovine adrenal cells: purification of a novel protein. Endocrinology. 123:2075-2082.

48. Besman, M. J., K. Yanagibashi, T. D. Lee, M. Kawamura, P. F. Hall, and J. E. Shively. 1989. Identification of des-(Gly-Ile)-endozepine as an effector of corticotropin-dependent adrenal steroidogenesis: stimulation of cholesterol delivery is mediated by the peripheral benzodiazepine receptor. Proc. Natl. Acad. Sci. USA. 86:4897-4901.

49. Pedersen, R. C., and A. C. Brownie. 1983. Cholesterol side-chain cleavage in the rat adrenal cortex: isolation of a cycloheximide-sensitive activator peptide. Proc. Natl. Acad. Sci. USA. 80:1882-1886.

50. Pedersen, R. C., and A. C. Brownie. 1987. Steroidogenesis activator polypeptide isolated from a rat Leydig cell tumor. Science (Wash. DC). 236:188-190.

51. Li, X., D. W. Warren, J. Gregoire, R. C. Pedersen, and A. S. Lee. 1989. The rat 78,000 dalton glucose-regulated protein (GRP78) as a precursor for the rat steroidogenesis-activator polypeptide (SAP): the SAP coding sequence is homologous with the terminal end of GRP78. Mol. Endocrinol. 3:1944-1952.

52. Schmitz, G., and G. Assman. 1989. Acid lipase deficiency: Wolman's disease and cholesteryl ester storage disease. In The Metabolic Basis of Inherited Disease. 6th ed. C. R. Scrirer, A. L. Beaudet, W. S. Sly, and D. Valle, editors. McGraw-Hill Book Co., New York. 1623-1644. 